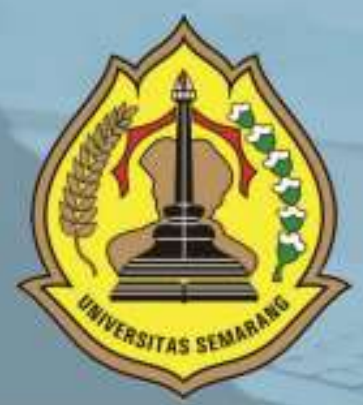

PENGARUH WORK FAMILY CONFLICT, STRES KERJA DAN KEPEMIMPINAN TERHADAP TURNOVER INTENTION KARYAWAN (STUDI PADA SELURUH KARYAWAN BAGIAN PLANNING PRODUCTION AND INVENTORY CONTROL PT. PARKLAND WORLD INDONESIA JEPARA

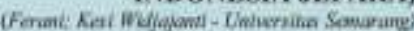

STUDI SOFT SKILL LULUSAN PENDIDIKAN KEJURUAN DI TEMPAT KERJA

Whort-Chiversikio Semorang

ANALISIS IINGKUNGAN INTERNAL DAN EKSTERNAL, PADA UKM PREMIUM PLUS LAUNDRY CABANG MULAWARMAN SEMARANG

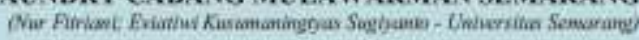

FAKTOR-FAKTOR YANG MEMPENGARUHI PERTIMBANGAN TINGKAT MATERIALITAS AUDIT

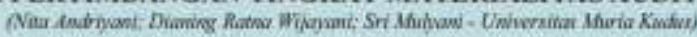

MANAJEMEN LABA DAN FAKTOR-FAKTOR YANG MEMPENGARUHINYA (STUDI EMPIRIS PADA PERUSAHAN MANUFAKTUR DI BEI)

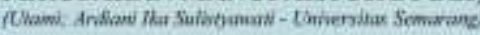

PENDAPATAN ASLI DAERAH, DANA PERIMBANGAN, DAN SISA LEBIH PEMBIAYAAN ANGGARAN TERHADAP PENGALOKASIAN BELANJA MODAL: STUDI PADA KABUPATEN/KOTA DI PROVINSI JAWA TENGAH

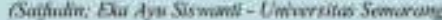

PERSEPSI PENGGUNA JASA TRANS JATENG TERHADAP KUALITAS PELAYANAN ANGKUTAN AGLOMERASI PERKOTAAN TRANS

JATENG

(Studi Kasus Trans Jateng Koridor I Semarang (Tawang) - Bawen)

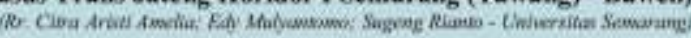

WORTHLESSNESS IS A POWER: MENGAPA ORANG BERSEDIA MENARUH UANG DI APLIKASI GO-PAY

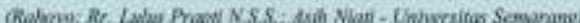

ANALISIS PENGARUH KUALITAS PRODUK, PERSEPSI HARGA, DAN PROMOSI TERHADAP KEPUTUSAN PEMBEIIAN WELLBLUE AL KALINE WATER PITCHER

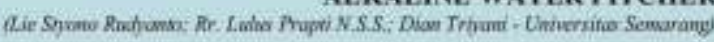

STRATEGI PEMASARAN UNTUK MENINGKATKAN VOLUME PENJUALAN (STUDI KASUS PADA SHOFA CATERING)

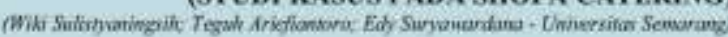

PENGARUH CITRA MEREK, PERSEPSI HARGA, DAN KUALITAS PRODUK TERHADAP KEPUTUSAN PEMBELIAN SEPATU OLAH RAGA MEREK ADIDAS

(Studi di Kota Semarang)

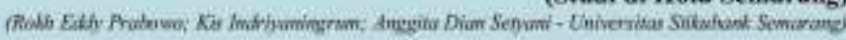

PENGARUH KEMUDAHAN TERHADAP KEPUTUSAN MENGGUNAKAN E-BANKING PADA BNI 46 KC KARANGAYU SEMARANG DENGAN MINAT NASABAH DAN KEPERCAYAAN SEBAGAI VARIABEL. MEDIASI

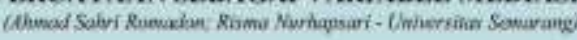

PENELITLAN KEBERLANGSUNGAN USAHA ARDANI INDONESIA SEBAGAI UMKM BERBASIS INDUSTRI KREATIF

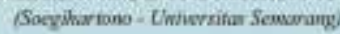

STRATEGI PELAYANAN BUS RAPID TRANSIT (BRT) TRANS SEMARANG

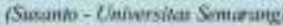

ANALISIS PENGARUH KEPEMIMPINAN, STRES KERJA, DAN LINGKUNGAN KERJA TERHADAP KINERJA KARYAWAN BAGIAN PRODUKSI SEWING PT. SAMWON BUSANA INDONESIA SEMARANG

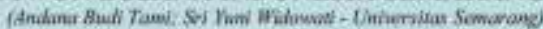




\section{DESKRIPSI}

Majalah IImiah Solusi Mengkaji

Masalah-Masalah Sosial,

Ekonomi dan Bisnis

\section{KETERANGAN TERBIT}

Terbit Pertama Kali Juli 2002

dan SelanjutnyaTerbit Tiga Bulan

Sekali (Januari, April, Juli dan

Oktober)

\section{PENERBIT}

Fakultas Ekonomi USM

\section{ALAMAT PENERBIT}

JL. Soekarno Hatta Semarang

Telp. 024-6702757 Fax. 024-6702272

\section{PENGELOLA}

Editor in Chief : Yohanes Suhardjo, SE, M.Si., Ak, CA Vice Editor Chief : Sugeng Rianto, SE, MM

Managing Editor: Edy Suryawardana, SE, MM

Secretary of Managing Editor : Asih Niati, SE, MM

Administration \& Circulation :

Citra Rizkiana, SE, MM

Layout \& Typesetting : M Burhan Hanif S.Kom, M.Kom

Board of Editors:

1. Prof. Dr. Ir. Kesi Widjajanti, SE, MM (USM)

2. Prof. Drs. Mohammad Nasir, Msi, Ph.D, AK. (USM)

3. Prof. Supramono SE, MBA, DBA (UKSW)

4. Prof. Drs. H. Imam Ghozali, M.Com, Akt, PhD (UNDIP)

5. Prof. Dr. Agus Suroso, MS (UNSOED)

6. Prof. Dr. Widodo, SE, M.Si (UNISSULA)

7. Prof. Dr. Dra. Sulastri, ME, M.Kom (UNSRI)

8. Dr. Ardiani Ika S, SE, MM, Ak, CA, CPA (USM)

\section{KATA PENGANTAR}

Sungguh merupakan kebahagiaan tersendiri bagi kami, takala kami dapat hadir rutin setiap tiga bulan sekali untuk saling bertukar pikiran mengenai hal-hal baru dibidang sosial, ekonomi dan bisnis.

Pada kesempatan ini penerbit menyampaikan terima kasih kepada semua pihak yang telah mengirimkan artikel-artikelnya. Penerbit akan membuka kesempatan seluas-luasnya bagi seluruh kalangan akademisi maupun praktisi baik dari dalam maupun luar Universitas Semarang untuk mempublikasikan karya ilmiahnya.

Penerbitan majalah ilmiah "SOLUSI" kali ini menghadirkan 15 (Lima Belas) artikel yang kami anggap layak untuk diterbitkan, dengan harapan dapat menjadi tambahan referensi bagi para pembaca dan menjadi sumbangan pengembangan persemaian khasanah pengetahuan dibidang sosial, ekonomi dan bisnis.

Akhir kata semoga majalah ilmiah "SOLUSI" dapat memberi manfaat yang sebesar-besarnya.

Hormat Kami 


\section{DAFTAR ISI}

PENGARUH WORK FAMILY CONFLICT, STRES KERJA DAN KEPEMIMPINAN TERHADAP TURNOVER INTENTION KARYAWAN (STUDI PADA SELURUH KARYAWAN BAGIAN PLANNING PRODUCTION AND INVENTORY CONTROL PT. PARKLAND WORLD INDONESIA JEPARA)

(Ferani; Kesi Widjajanti - Universitas Semarang)

STUDI SOFT SKILL LULUSAN PENDIDIKAN KEJURUAN DI TEMPAT KERJA

(Albert - Universitas Semarang)...

ANALISIS LINGKUNGAN INTERNAL DAN EKSTERNAL PADA UKM PREMIUM PLUS

LAUNDRY CABANG MULAWARMAN SEMARANG

(Nur Fitriani; Eviatiwi Kusumaningtyas Sugiyanto - Universitas Semarang)

FAKTOR-FAKTOR YANG MEMPENGARUHI PERTIMBANGAN TINGKAT

MATERIALITAS AUDIT

(Nita Andriyani; Dianing Ratna Wijayani; Sri Mulyani - Universitas Muria Kudus).

MANAJEMEN LABA DAN FAKTOR-FAKTOR YANG MEMPENGARUHINYA

(STUDI EMPIRIS PADA PERUSAHAN MANUFAKTUR DI BEI)

(Utami; Ardiani Ika Sulistyawati - Universitas Semarang)

PENDAPATAN ASLI DAERAH, DANA PERIMBANGAN, DAN SISA LEBIH PEMBIAYAAN ANGGARAN TERHADAP PENGALOKASIAN BELANJA MODAL: STUDI PADA

KABUPATEN/KOTA DI PROVINSI JAWA TENGAH

(Saifudin; Eka Ayu Siswanti - Universitas Semarang).

PERSEPSI PENGGUNA JASA TRANS JATENG TERHADAP KUALITAS PELAYANAN ANGKUTAN AGLOMERASI PERKOTAAN TRANS JATENG

(Studi Kasus Trans Jateng Koridor I Semarang (Tawang) - Bawen)

(Rr. Citra Aristi Amelia; Edy Mulyantomo; Sugeng Rianto - Universitas Semarang)

WORTHLESSNESS IS A POWER: MENGAPA ORANG BERSEDIA MENARUH UANG DI APLIKASI GO-PAY

(Rahoyo; Rr. Lulus Prapti N.S.S.; Asih Niati - Universitas Semarang).

ANALISIS PENGARUH KUALITAS PRODUK, PERSEPSI HARGA, DAN PROMOSI TERHADAP KEPUTUSAN PEMBELIAN WELLBLUE ALKALINE WATER PITCHER

STRATEGI PEMASARAN UNTUK MENINGKATKAN VOLUME PENJUALAN (STUDI KASUS PADA SHOFA CATERING)

(Wiki Sulistyaningsih; Teguh Ariefiantoro; Edy Suryawardana - Universitas Semarang)

PENGARUH CITRA MEREK, PERSEPSI HARGA, DAN KUALITAS PRODUK TERHADAP KEPUTUSAN PEMBELIAN SEPATU OLAH RAGA MEREK ADIDAS

(Studi di Kota Semarang)

(Rokh Eddy Prabowo; Kis Indriyaningrum; Anggita Dian Setyani - Universitas Stikubank Semarang) .121

PENGARUH KEMUDAHAN TERHADAP KEPUTUSAN MENGGUNAKAN E-BANKING PADA BNI 46 KC KARANGAYU SEMARANG DENGAN MINAT NASABAH DAN KEPERCAYAAN SEBAGAI VARIABEL MEDIASI

(Ahmad Sahri Romadon; Risma Nurhapsari - Universitas Semarang) 
PENELITIAN KEBERLANGSUNGAN USAHA ARDANI INDONESIA SEBAGAI UMKM BERBASIS INDUSTRI KREATIF

(Soegihartono - Universitas Semarang)

STRATEGI PELAYANAN BUS RAPID TRANSIT (BRT) TRANS SEMARANG

(Susanto - Universitas Semarang).....

ANALISIS PENGARUH KEPEMIMPINAN, STRES KERJA, DAN LINGKUNGAN KERJA TERHADAP KINERJA KARYAWAN BAGIAN PRODUKSI SEWING PT. SAMWON BUSANA INDONESIA SEMARANG

(Andana Budi Tami; Sri Yuni Widowati - Universitas Semarang). 


\title{
WORTHLESSNESS IS A POWER: MENGAPA ORANG BERSEDIA MENARUH UANG DI APLIKASI GO-PAY
}

\author{
$\operatorname{Rahoyo~}^{1}$ \\ Rr. Lulus Prapti N.S.S. ${ }^{2}$ \\ Asih Niati $^{3}$ \\ stefanus.rahoyo1970@gmail.com ${ }^{1}$ \\ Fakultas Ekonomi Universitas Semarang
}

Diterima: Agustus 2020, Disetujui: September 2020, Dipublikasikan: Oktober 2020

\begin{abstract}
One of the backbones of Go-jek's revenue is the Go-pay transaction. In contrast to banks where customers can easily find the bank office where they put money; on the Go-pay app consumers don't even know where the Go-pay office is. Why are these consumers willing to put money in the Go-pay application without knowing where the Go-pay office is or even not knowing how the procedure is and where to complain if at any time their money in the Go-pay application is lost?

Through a qualitative approach, this research finds that trust is not the main factor that makes these consumers willing to put money in the Go-pay application but is worthlessness.
\end{abstract}

Keywords: Go-jek, Go-pay, trust, digital economy

\begin{abstract}
ABSTRAK
Salah satu tulang punggung revenue Go-jek adalah transaksi pembayaran Gopay. Berbeda dengan bank di mana nasabah bisa dengan mudah menemukan kantor bank tempatnya menaruh uang; pada aplikasi Go-pay konsumen bahkan tidak tahu di mana kantor Go-pay. Mengapa para konsumen tersebut bersedia menaruh uang di aplikasi Go-pay tanpa mengetahui di mana kantor Go-pay bahkan juga tidak mengetahui bagaimana prosedur dan ke mana harus komplain bila sewaktu-waktu uang mereka di aplikasi Go-pay hilang?

Melalui pendekatan kualitatif penelitian ini menemukan bahwa trust atau kepercayaan bukanlah faktor utama yang membuat para konsumen tersebut bersedia menaruh uang di aplikasi Go-pay melainkan ketidakbernilaian (worthlessness).
\end{abstract}

Kata Kunci: Go-jek, Go-pay, trust, ekonomi digital.

\section{PENDAHULUAN}

Kontribusi ekonomi digital (digital economy) terhadap Produk Domestik Bruto (PDB) memang masih relatif kecil, tetapi tidak bisa dipandang sebelah mata. Tahun 2017 ekonomi digital menyumbang Rp125 triliun. Jumlah itu meningkat 5,5 kali lipat 
pada tahun 2018, yakni menjadi Rp814 triliun [ (Bisnis, 2019), (Katadata, 2019)]. Institute for Development of Economics and Finance (INDEF) bahkan mengungkapkan bahwa ekonomi digital telah menambah 5,7 juta lapangan kerja Indonesia 2018. Tahun 2030 ekonomi digital diperkirakan akan melejit dan mampu menyumbang sebesar Rp2.300-an triliun terhadap PDB (Bisnis, 2019).

Lebih jauh Indef mengeksplorasi kontribusi ekonomi digital tersebut dengan merinci besaran PDB per sektor berdasarkan pengeluaran (by expenditure) tahun 2018 sebagaimana terlihat pada tabel berikut.

Tabel 1.

\section{Besaran PDB Per Sektor Berdasarkan Pengeluaran tahun 2018} (Triliun Rupiah)

\begin{tabular}{|l|l|l|l|l|l|}
\hline \multirow{2}{*}{$\begin{array}{l}\text { KOMPONEN } \\
\text { PENGELUARAN }\end{array}$} & \multicolumn{2}{|l|}{ Digital Ec. } & & \multicolumn{2}{|l|}{ GDP Indonesia } \\
\cline { 2 - 5 } & PDB & $\%$ & & PDB & $\%$ \\
\hline Belanja Pemerintah (G) & 37,53 & 9 & & $1.332,53$ & 9.3 \\
\hline Investasi (I) & 48,84 & 11.7 & $4.790,61$ & 33.6 \\
\hline Konsumsi RT (C) & 331,32 & 79.3 & $8.269,75$ & 58 \\
\hline Net Trade (X-M) & & & $-161,77$ & -0.7 \\
\hline
\end{tabular}

Sumber: Teknologi Bisnis, 2019

Data di atas menunjukkan bahwa tahun 2018 baik PDB sektor ekonomi digital maupun PDB Indonesia sebagian terbesar disumbang oleh konsumsi rumah tangga, masing-masing sebesar 79\% dan 58\%.

Yang tidak boleh diabaikan ketika mengulas sumbangan sektor digital economy terhadap PDB atau PDRB adalah peran Go-pay sebagai salah satu aplikasi dompet virtual; selain Ovo, Dana, dan LinkAja. Memang, survei yang dilakukan Mckinsey menyimpulkan bahwa $99 \%$ transaksi by volume masih dilakukan dengan uang tunai (CNBC, 2019). Tetapi, nilai transaksi Go-pay yang mencapai 87 triliun sepanjang tahun 2018 (CNBC, 2019) dan bahkan per Februari 2019 telah mencapai Rp89,5 triliun (Katadata, 2019); aplikasi ini menjadi sangat strategis untuk menyokong perkembangan digital economy guna menopang PDB dan PDRB di masa depan.

Persoalannya, berbagai kasus Go-pay terjadi, misalnya tiba-tiba e-banking melakukan transfer ke Go-pay tanpa perintah si pemilik akun; ketika melakukan top up melalui e-banking, saldo bank berkurang tetapi saldo Go-pay tidak bertambah; melakukan dua kali top up tetapi yang tercatat hanya yang kedua (Indonesia, 2019). Bahkan belum lama ini, akun Go-pay selebritas Aura Kasih dan Maia Istianti diretas dan akibatnya, puluhan juta uang yang ada di Go-pay tergasak (Kontan, 2020). Timbul pertanyaan, mengapa dan bagaimana konsumen bersedia menaruh uang di Go-pay padahal aplikasi ini tidak luput dari risiko? 


\section{TINJAUAN PUSTAKA}

\section{Digital Economy}

Digital economy terkait erat dengan Internet. Bahkan, digital economy itu sendiri bisa diartikan sebagai ... the economic activity with help of mobile technology and the internet of things (Iot) that result from billions of everyday online connections among people, businesses, devices, machines, data, and processes (Gorog, 2018). Dari definisi tersebut bisa ditarik kesimpulan bahwa Internet merupakan tiang penyangga digital economy, selain teknologi seluler sebagai tiang penyangga lainnya. Internet melalui teknologi seluler menghubungkan orang, bisnis, alat, mesin, data dan proses secara daring (online). Hubungan daring tersebut jumlahnya miliaran setiap harinya. Hubungan daring antar-orang, antar-bisnis, dsb tersebut pada akhirnya menciptakan aktivitas ekonomi. Itulah yang kemudian disebut sebagai ekonomi digital atau digital economy.

Dari kacamata ekonomi, bagaimanapun digital economy telah mengubah ekosistem bisnis. Berbeda dengan ekonomi konvensional, digital economy berkarakter inklusif (siapa pun bisa menjadi produsen dan konsumen) dan memberikan ekualitas peluang bagi semua orang. Salah satu contoh perubahan ekosistem akibat inklusivitas dan ekualitas tersebut, misalnya, betapa para entrepreneur kecil sekalipun kini bisa bersaing dan bahkan merebut pasar dengan mengikuti perkembangan teknologi (Novitasyari \& Widiastuti, 2019). Hal itu bisa terjadi karena dengan adanya digital economy para entrepreneur kecil tidak lagi terbatasi oleh aspek geografis (borderless) bahkan modal. Dengan sendirinya, digital economy sekaligus membuka peluangpeluang baru untuk mendapatkan pendapatan atau menjalankan bisnis (CornejoVelazques, Clavel-Maqueda, Perez-Lopez-Portillo, \& Lyubimova, 2020).

Digital economy juga memungkinkan peluang sharing yang semakin luas dalam sharing economy ${ }^{l}$ (Celata, Hendrickson, \& Sanna, 2017). Bagi konsumen, digital economy merupakan alternatif yang sangat menarik karena memberikan berbagai benefit ekonomis, misalnya memungkinkan konsumen mendapatkan barang atau jasa dengan harga yang lebih murah. Perubahan ekosistem bisnis tersebut, dari kacamata manajemen, pada akhirnya menuntut para pelaku bisnis untuk mendeskripsikan, mendesain ulang dan melakukan pembersihan beberapa aspek bisnis ke dalam sebuah strategi bisnis keseluruhan (Sawitri \& Suswanti, 2019).

Infrastruktur yang lahir mengikuti digital economy yang kemudian sekaligus menjadi salah satu penopang dan bahkan penentu eksistensi digital economy adalah pembayaran non-tunai (cashless payment). Bisa dibayangkan betapa digital economy akan terseok-seok apabila pembayaran masih harus dilakukan secara tunai. Di sisi lain, pembayaran non-tunai sekaligus jauh lebih menarik daripada pembayaran tunai bagi

\footnotetext{
${ }^{1}$ Untuk definisi sharing economy silakan baca: (Cornejo-Velazques, Clavel-Maqueda, Perez-LopezPortillo, \& Lyubimova, 2020), (Decrop \& Graul, 2019), (Gorog, 2018).
} 
orang dan terutama para pelaku ekonomi yang menghendaki kepraktisan segala aktivitas mereka (Novitasyari \& Widiastuti, 2019).

Dalam konteks penelitan ini, aplikasi Go-pay merupakan serambi (platform) untuk memfasilitasi pembayaran non-tunai tersebut.

\section{Trust}

Bagaimana orang bersedia mengambil risiko uangnya di aplikasi Go-pay hilang karena berbagai sebab? Beberapa penelitian mengaitkannya dengan kepercayaan atau trust. Anjar Priyono, misalnya, menyimpulkan bahwa tingkat penerimaan terhadap teknologi pembayaran elektronik dipengaruhi oleh kepercayaan dan risiko (Priyono, 2017). Tidak hanya berpengaruh terhadap penerimaan teknologi pembayaran elektronik, trust bahkan merupakan dasar dan faktor kunci terjadinya transaksi dalam sharing economy [ (Cornejo-Velazques, Clavel-Maqueda, Perez-Lopez-Portillo, \& Lyubimova, 2020), (Huurne, Ronteltap, \& Buskens, 2020)]. Tidak cukup sampai di situ, Fukuyama dalam bukunya yang berjudul Trust bahkan menyimpulkan negara-negara dengan tingkat kepercayaan yang tinggi (high trust) seperti Amerika Serikat, Jepang dan Jerman terbukti mampu menciptakan perusahaan-perusahaan berskala besar dibandingkan dengan negara-negara dengan tingkat kepercayaan yang rendah (low trust), seperti Hong Kong dan Taiwan (Fukuyama, 2010). ${ }^{2}$ Ini berarti bahwa apabila orang bersedia menggunakan serambi (platform) ekonomi digital artinya orang tersebut menaruh kepercayaan kepada serambi tersebut. Menariknya, Decrop dalam penelitiannya tahun 2019 di Amerika menyatakan bahwa 67\% responden menyatakan, kekhawatiran atas trust merupakan penghalang utama penggunaan platform sharing economy (Decrop \& Graul, 2019).

Fukuyama mendefinisikan trust sebagai “... harapan yang muncul dalam sebuah komunitas yang berperilaku teratur, jujur, dan kooperatif, berdasarkan norma-norma yang dimiliki bersama...." (Fukuyama, 2010). Definisi yang lebih tegas dikemukakan Priyono. Ia mendefinisikan trust sebagai kesediaan untuk menjadi tidak pasti sebagai akibat dari penyerahan sesuatu kepada pihak lain (Priyono, 2017). Dalam hal aplikasi Go-pay, konsumen bersedia menyerahkan uang kepada PT Go-jek sebagai pemilik dan penyedia aplikasi Go-pay tanpa kepastian bahwa uang tersebut pasti aman. Dan dari definisi yang dikemukanan Fukuyama mengenai trust, bisa ditarik kesimpulan bahwa trust muncul dalam suatu komunitas karena adanya nilai-nilai yang dianut, diyakini dan diterapkan bersama (common values) [ (Celata, Hendrickson, \& Sanna, 2017), (Huurne, Ronteltap, \& Buskens, 2020)].

\footnotetext{
${ }^{2}$ Untuk data skala perusahaan berdasarkan revenue dalam jutaan dolar AS yang menjadi dasar kesimpulan Fukuyama, lihat Fukuyama.Trust: Kebajikan Sosial dan Penciptaan Kemakmuran (terj.)(Yogyakarta: Penerbit Qalam, 2010), hlm. 46.
} 
Menariknya, dalam penelitian ini, para informan bersedia menaruh uang mereka di aplikasi Go-pay bukan pertama-tama karena trust melainkan karena nominal uang yang mereka serahkan tersebut bagi mereka nilainya relatif kecil atau kurang bahkan tidak bernilai (worthless). Temuan ini sekaligus mengisi celah paparan Fukuyama mengenai norma (norms) sebagai dasar hadirnya trust (Fukuyama, 2010). Salah satu "jenis" norma yang disebut Fukuyama adalah norma profesional. Dalam paparannya mengenai norma profesional itu Fukuyama memberikan contoh sebagai berikut: pasien yakin dokter tidak akan dengan sengaja menyakiti dirinya karena ia percaya dokter bekerja dengan kode etik dan standar profesi medis. Trust dalam hal ini berarti si pasien bersedia menyerahkan tubuhnya untuk dioperasi dokter, misalnya, karena pasien yakin dokter tidak akan dengan sengaja menyakitinya tanpa ada kepastian ia pasti sembuh.

Dalam kasus Go-pay, tentu saja Go-pay juga memiliki kode etik profesional, misalnya Go-pay akan mengganti uang konsumen yang tiba-tiba hilang karena sistem. Norma tersebut tentu saja disadari oleh konsumen. Tetapi, konsumen (dalam hal ini para informan) bersedia menyerahkan uangnya kepada Go-jek bukan atas dasar keyakinan adanya norma tersebut.

Tampak bahwa norma profesional melahirkan trust sebagaimana dikemukan Fukuyama hanya relevan ketika nilai sesuatu yang diserahkan oleh seseorang kepada pihak lain sangat berharga (dalam contoh dokter yang dikemukakan Fukuyama, yang diserahkan pasien adalah kesembuhan, keselamatan bahkan nyawanya!). Akan tetapi, dalam kasus Go-pay, para informan bersedia menyerahkan uangnya kepada Go-jek bukan pertama-tama karena para informan yakin akan standar profesionalitas Go-jek melainkan karena apa yang mereka serahkan kepada Go-jek tersebut bernilai kecil (worthless)!

\section{METODOLOGI}

Penelitian mengenai mengapa dan bagaimana orang bersedia menaruh uang di aplikasi Go-pay padahal aplikasi tersebut tidak luput dari risiko ini dikerjakan dengan pendekatan kualitatif. Dengan pendekatan kualitatif artinya peneliti ingin mencari tahu apa yang dipikirkan dan dirasakan informan kunci sehingga mereka bertindak dalam cara tertentu (Rahoyo\&Prapti, 2020). Tujuan dari penelitian ini adalah menggambarkan fenomena orang bersedia menaruh uang di suatu aplikasi virtual dan menjelaskan sebabsebab fenomena itu terjadi. Penelitian ini dengan demikian sekaligus bercorak deskriptif-eksplanatoris (Rahoyo \& Prapti NSS, 2019). Untuk memperoleh data, peneliti melakukan wawancara mendalam (indepth interview) terhadap 5 orang informan kunci (key informants). Profil informan terlihat dalam tabel 2 di bawah ini. 
Tabel 2.

Profil Informan

\begin{tabular}{|l|l|l|l|l|}
\hline INFORMAN & $\begin{array}{l}\text { JENIS } \\
\text { KELAMIN }\end{array}$ & UMUR & PEKERJAAN & $\begin{array}{l}\text { PENGHASILAN } \\
\text { PER BULAN }\end{array}$ \\
\hline Informan 1 & Laki-laki & 25 tahun & Wiraswasta & $0-10$ juta \\
\hline Informan 2 & Perempuan & 52 tahun & Karyawan & $10-20$ juta \\
\hline Informan 3 & Perempuan & 22 tahun & Mahasiswa & $0-10$ juta \\
\hline Informan 4 & Perempuan & 54 tahun & Dosen & $0-10$ juta \\
\hline Informan 5 & Laki-laki & 35 tahun & Karyawan & $10-20$ juta \\
\hline
\end{tabular}

Semua informan berdomisili di Semarang. Wawancara dilakukan dengan dua metode: (1) tatap muka dan (2) melalui telepon. Wawancara melalui telepon terpaksa dilakukan karena ketika penelitian ini dilakukan, pandemi Covid-19 sedang melanda Semarang, Indonesia bahkan dunia. Semua wawancara yang berlangsung sekitar $10-20$ menit direkam untuk kemudian ditranskrip.

Hasil transkrip seluruh wawancara selanjutnya diklasifikasikan berdasarkan pertanyaan untuk selanjutnya dianalisis dan dijadikan dasar pembuatan laporan.

\section{HASIL DAN PEMBAHASAN}

Tidak ada pola konsisten antara besarnya income (pendapatan) para informan dengan besarnya saldo di dompet virtual Go-pay pun pula besarnya top up per periode. Informan 4, misalnya, mengatakan, “... Saya tidak penah top up kecil... rata-rata itu, ya... 500.000 per minggu. "3

Menurut informan 4, dia setiap minggu melakukan pengisian atau top up Go-pay sebesar Rp500.000. Nilai top up ini sekitar 5\% dari total penghasilannya sebulan yang sebesar 0-10 juta per bulan. Persentase top up ini terlihat sangat besar bila dibandingkan dengan informan 2. Informan 2 menyatakan, penghasilan dia 10-20 juta per bulan tetapi untuk top up dompet virtual Go-pay hanya 50.000 maksimal 100.000 per minggu. Ini berarti bahwa nilai top up informan 2 dibandingkan dengan penghasilannya sebulan tidak sampai $1 \%$. Demikian pula dengan informan 1. Dengan penghasilan 0-10 juta sebulan; ia melakukan top up Go-pay senilai 55.000-100.000 per minggu. Atau informan 5 yang nilai top up-nya rata-rata Rp400.000 per minggu dengan penghasilannya sebesar Rp10.000.000 - Rp20.000.000.

\footnotetext{
${ }^{3}$ Wawancara tanggal 5 Mei 2020
} 


\section{Tergantung Kebutuhan}

Berdasarkan informasi yang diperoleh dari para informan kunci, bisa ditarik kesimpulan bahwa tidak ada korelasi positif antara tingkat penghasilan dengan besarnya nominal nilai top up seseorang di Go-pay. Seseorang dengan penghasilan yang lebih besar daripada penghasilan orang lain belum tentu melakukan top up Go-pay dengan nilai nominal yang lebih besar pula daripada orang lain tersebut. Sekalipun demikian, tidak berarti tidak ada konsistensi jawaban para informan untuk mengetahui apakah faktor yang mempengaruhi besar-kecilnya seseorang melakukan top up Go-pay.

Dari awal (saya) tidak pernah top up kecil karena memang kebutuhannya

banyak, ya. Untuk konsumsi itu kan sekali (transaksi) bisa 30-40 (ribu);

bahkan kalau satu keluarga bisa hampir 100 (ribu). ${ }^{4}$

Jadi, menurut informan 4, ia melakukan top up dalam nilai nominal Rp500.000 per minggu karena kebutuhan dia untuk transaksi melalui Go-pay memang sebesar itu. Pernyataan informan 4 ini senada dengan informasi yang diberikan oleh semua informan. Informan 3, misalnya, yang sekali top up sebesar Rp50.000, itu pun waktunya tidak tentu, mengatakan, "Kalau waktu (top up)-nya sih tidak tertentu. Tergantung kalau misalnya dibutuhkan." Informan 5 memberikan jawaban lebih eksplisit mengenai hal ini.

Mengapa (nilai nominal top up) Rp200.000? Itu karena kebutuhan saya untuk transaksi maksimal senilai itu... Jadi, plafonku untuk entertaint " $x$ " itu senilai itu.

Informan 5 adalah seorang salesman. Sebagai salesman dia seringkali harus melakukan entertaint kepada kliennya. Perusahaan tempatnya bekerja menetapkan plafon untuk sekali entertain sebesar Rp200.000. Entertain ini dalam bentuk, biasanya, diminta klien membelikan makanan.

Semua informan konsisten memberikan informasi bahwa besar-kecilnya mereka melakukan top up tergantung pada kebutuhan. Informan 4 melakukan top up hingga Rp500.000 per minggu karena kebutuhan untuk go-food juga sebesar itu dalam seminggu. Informan 2 melakukan top up hanya senilai 50-100 ribu karena kebutuhan dia untuk membayar transportasi go-jek memang hanya senilai itu dalam seminggu.

Dengan demikian, besar-kecilnya nominal nilai top up Go-pay seseorang lebih ditentukan oleh faktor kebutuhan daripada faktor penghasilan seseorang.

\section{Berjaga-jaga}

Informan 5 menceritakan, saldo di Go-pay ia jaga sekitar Rp200.000. Saldo itu hampir selalu terpakai dalam 2 atau 3 hari. Karena itu, dalam seminggu ia harus melakukan top up sekitar Rp400.000. ${ }^{6}$ Saldo senilai Rp200.000 tersebut ia biarkan supaya sewaktu-waktu harus meng-entertain klien, ia tidak repot.

\footnotetext{
${ }^{4}$ Wawancara dengan informan 4 tanggal 5 Mei 2020

${ }^{5}$ Wawancara dengan informan 3, 28 April 2020

${ }^{6}$ Wawancara 15 Mei 2020
} 
Motif untuk berjaga-jaga semacam ini rupanya juga dilakukan oleh informan 2 dan 4. Kedua informan menaruh uang mengendap di Go-pay untuk berjaga-jaga bila sekali waktu butuh makanan lewat go-food atau untuk membayar transportasi go-jek. Oleh karena itu, bisa dipahami, selain nilai nominal top up yang berbeda antar-informan dan itu tidak tergantung pada besar-kecilnya pendapatan; nilai saldo informan di akun Go-pay masing-masing juga berbeda. Besar-kecilnya saldo ini terkait erat dengan motif berjaga-jaga untuk kebutuhan mereka yang hampir bisa dipastikan dan rutin, misalnya untuk membayar go-jek saban hari, menjamu klien di mana plafon untuk menjamu tersebut telah ditetapkan, atau untuk membeli makanan lewat akun go-food karena kesibukan sehari-hari.

Motif seperti di atas tidak tampak pada informan 1 dan 3. Keduanya baru akan melakukan top up apabila membutuhkannya. Misalnya, cerita informan 3, "Saldo ratarata (di Go-pay) di bawah 10.000. Kalau pas mau beli-beli baru diisi." "7 Menurut informan 3, apabila tidak digunakan, saldo uangnya di Go-pay maksimal 10.000. Ketika ia akan membeli suatu barang, katakanlah harga barang tersebut Rp25.000; ia baru akan melakukan top up, misalnya Rp20.000. Senada dengan informan 3, informan 1 juga melakukan seperti yang dilakukan oleh informan 3. Saldo uang pribadinya di Go-pay bahkan tidak ada. Kalaupun saat ini di dompet virtual Go-pay-nya masih ada saldo, itu adalah saldo dari cashback pembelian sesuatu yang ia lakukan. Ia selalu melakukan top up senilai harga barang atau makanan yang akan ia beli dan itu dia lakukan ketika akan membeli barang atau makanan.

Yang menarik adalah, baik untuk informan yang punya motif berjaga-jaga maupun yang tidak, keduanya konsisten menceritakan bahwa pada awalnya mereka menggunakan aplikasi Go-pay karena tertarik dengan potongan harga dan promosipromosi penjualannya. Yang dimaksud potongan harga dan promosi penjualan adalah, apabila informan menggunakan jasa Go-jek, ia sebenarnya bisa saja membayar memakai uang tunai. Namun, apabila informan tersebut membayar ongkos go-jek dengan menggunakan aplikasi Go-pay, dengan jarak yang sama ia akan membayar lebih murah daripada membayar dengan uang tunai. Demikian juga untuk aplikasi go-food. Ongkos kirim akan dibayar informan lebih murah apabila ia membayar dengan Go-pay bukan dengan uang tunai. Go-pay juga memberikan promosi penjualan. Untuk kopi merek "A" yang di counter harganya Rp25.000, informan bisa mendapatkan discount, misalnya $10 \%$ apabila ia membayar menggunakan Go-pay dan harus membayar penuh Rp25.000 apabila ia membayar kopi yang sama menggunakan uang tunai.

\section{Worthlessness Is a Power}

Orang mengenal dan pada akhirnya menggunakan aplikasi Go-pay melalui berbagai saluran promosi yang dilakukan Go-pay: melalui aplikasi go-jek, pengemudi go-jek, iklan di media sosial, iklan di televisi bahkan dari teman dengan iklan dari mulut ke mulut. Tujuan awal menggunakan Go-pay pun beraneka ragam: sekadar untuk

\footnotetext{
${ }^{7}$ Wawancara 28 April 2020
} 
membayar ongkos go-jek, membeli makanan lewat aplikasi go-food, atau untuk sekadar untuk mendapatkan discount saat membeli sesuatu.

Tetapi, hal yang menarik adalah, mengapa dan bagaimana para pengguna aplikasi Go-pay bersedia menyerahkan uangnya yang bahkan sampai Rp400.000 sampai Rp500.000 per minggu dan mengendap di suatu dompet "tanpa memikirkan risiko"? Walaupun belum pernah mengalami sendiri, semua informan mengaku pernah membaca atau mendengar kasus uang hilang (karena penipuan atau pembobolan) di aplikasi Gopay. Artinya, mereka tahu bahwa menaruh uang di Go-pay berisiko hilang. Semua informan dengan tegas menyatakan tidak tahu prosedurnya seperti apa, komplainnya harus ke mana bila mendadak uang mereka di Go-pay hilang. ${ }^{8}$ Tetapi, anehnya, semua informan menyatakan tidak merasa khawatir uang mereka akan hilang. Benarkah ini adalah sebuah kepercayaan (trust)?

(Saya tidak khawatir) karena saya taruh (uang di Go-pay) sedikit. Orang kalau mau membobol rekening saya kan rugi... Saya sama sekali tidak memikirkan risikonya.... Jadi, waktu top-up saya tidak pakai pertimbangan macam-macam. Pokoknya saya kasih Rp50.000 atau Rp100.000. ${ }^{9}$

Menurut informan, ia tidak merasa khawatir uangnya akan hilang atau dibobol karena nominal uangnya di rekening Go-pay kecil. Tidak saja kecil, bagi informan, nilai Rp50.000 - Rp100.000 relatif kurang bernilai tentu saja dibandingkan dengan manfaat yang ia peroleh dengan menggunakan Go-pay. Kekurangbernilaian saldo informan di rekening Go-pay tampak dari jawaban informan yang menyatakan bahwa ia sama sekali tidak memikirkan risiko ketika melakukan top up, tanpa pertimbangan macam-macam.

Tidak khawatir uang di Go-pay hilang atau dibobol karena nominalnya kecil merupakan jawaban konsisten semua informan, baik informan yang hanya top up Rp50.000 per minggu atau Rp500.000 per minggu; baik informan yang saldo di rekening Go-pay-nya Rp7.000 maupun yang Rp200.000. Semua informan juga konsisten tidak menempatkan faktor keamanan sebagai alasan nomor 1 mereka menaruh uang di Go-pay. Tiga informan menempatkan faktor keamanan tersebut di urutan ketiga setelah promosi dan kenyamanan dan dua informan menempatkannya di urutan kedua setelah kenyamanan! Jadi, jelaslah bahwa para informan tersebut menaruh uang di Gopay bukan pertama-tama karena trust, melainkan karena worthlessness.

Ketidakbernilaian (worthlessness) saldo pengguna aplikasi Go-pay tersebut di sisi lain justru telah menjadi kekuatan utama Go-jek. Menurut www.cnnindonesia.com, dua sumber pendapatan terbesar Go-jek adalah pertama dari transaksi Go-pay dan yang kedua adalah dari go-food. Dengan kata lain, kekuatan Go-jek salah satunya terletak pada worthlessness saldo konsumen. Dari kaca mata atau sudut pandang Go-jek,

\footnotetext{
8 Informan 1 tidak dengan tegas menjawab "tidak tahu" ketika ditanya, "Apakah Anda tahu bila tiba-tiba uang Anda di go-pay hilang harus komplain ke mana dan bagaimana prosedurnya?". Dia menjawab, "Kayaknya ada," lalu membuka-buka aplikasi cukup lama untuk menemukan fasilitas "help". Kalimat "kayaknya" dan waktu cukup lama mencari-cari fasilitas "help" di aplikasi go-pay menunjukkan bahwa pada dasarnya informan tidak atau belum tahu prosedur dan ke mana ia harus melakukan komplain apabila mendadak uangnya di go-pay hilang. (wawancara tanggal 13 Mei 2020).

${ }^{9}$ Wawancara tanggal 3 Mei 2020.
} 
worthlessness ini justru merupakan strategi perusahaan dalam memperoleh pendapatan dari pelanggan (revenue streams)!

\section{KESIMPULAN}

Trust bukan faktor utama yang membuat konsumen bersedia menaruh uang di aplikasi Go-pay. Kekurangbernilaian atau ketidakbernilaian (worthlessness) nominal uang konsumenlah yang membuat para konsumen Go-pay menaruh uang mereka tersebut. Dari sudut pandang Go-pay, worthlessness tersebut justru menjadi kekuatan bagi bisnis Go-jek. Terbukti, sekalipun berasal dari uang yang bagi konsumen "tidak bernilai", transaksi pembayaran Go-pay-selain go-food-telah menjadi sumber revenue utama bagi Go-jek.

\section{KETERBATASAN}

Bila aktivitas ekonomi tidak bisa dilepaskan dari sistem sosial (baca: kebudayaan) masyarakat setempat, penelitian ini belum mengkaji lebih dalam apakah fenomena sosial yang menjadi objek penelitian ini juga terkait dengan sistem sosial dan tingkat pendidikan masyarakat Semarang yang menjadi lokus penelitian ini.

\section{PENGHARGAAN}

Penghargaan pertama-tama penulis berikan kepada para informan kunci yang telah bersedia diwawancarai untuk keperluan penelitian ini. Penghargaan kedua diberikan kepada Lembaga Penelitian dan Pengabdian kepada Masyarakat (LPPM) Universitas Semarang (USM) yang telah mendanai penelitan ini.

\section{REFERENSI}

Bisnis, T. (2019, 2 13). Teknologi Bisnis. Retrieved from Teknologi.Bisnis.com

Celata, F., Hendrickson, C. Y., \& Sanna, V. S. (2017). The Sharing Economy as Community Marketplace? Trust, Reciprocity and Belonging in Peer-to-peer Accomodation Platforms. Cambridge Journal of Regions, Economy and Society Vol. 10, 349-363.

CNBC. (2019, 3 21). CNBC. Retrieved from CNBC: www.cnbc.com

Cornejo-Velazques, E., Clavel-Maqueda, M., Perez-Lopez-Portillo, H., \& Lyubimova, E. (2020). Business Model of Learning Paltforms in Sharing Economy. The Electronic Journal of E-Learning Vol. 18, 102-113.

Decrop, A., \& Graul, A. R. (2019). The Role of System Trust and Risk Perception in Providing Assets for Collaborative Consumption Schemes. Journal of Management for Global Sustainability Vol 7, 131-153.

Fukuyama, F. (2010). Trust (terj). Yogyakarta: Penerbit Qalam.

Gorog, G. (2018). The Definitions of Sharing Economy:. Management, 175-189. 
Huurne, T. M., Ronteltap, A., \& Buskens, V. (2020). Sense of Community and Trus in The Sharing Economy. Tourism Analysis Vol 25, 43-61.

Indonesia, C. (2019, 10 26). CNN Indonesia. Retrieved from CNN Indonesia: www.cnnindonesia.com

Katadata. (2019, 9 4). Kata Data. Retrieved from Databoks.katadta.co.id

Kontan. (2020, 1 20). Kontan. Retrieved from Kontan: www. keuangan.kontan.co.id

Novitasyari, A., \& Widiastuti. (2019). Cashless in Onlien Transportation Applications for Services Business. IOP Conference.

Priyono, A. (2017). Analisis Pengaruh Trust dan Risk dalam Penerimaan Teknoogi Dompet Elektronik Go-pay. Jurnal Siasat Bisnis Vol 21, 88-108.

Rahoyo\&Prapti.(2020). Disrupsi dari Atas: Kasus Bangkrutnya Kios Tradisional Berhadapan dengan Minimarket Modern. Dinamika Sosial Budaya Vol. 22, 8-20

Rahoyo\&Prapti. (2019). Bank Keliling Pemburu Rente dan Involusi Usaha Pedagang Pasar. Solusi Vol. 17, 165-191

Sawitri, D., \& Suswanti, E. (2019). Strategy for Diversifying Typical Snacks of Trenggalek Products to Increase Competitiveness in The Era of SDGs by Using Business Model Canvas. The International Journal of Organizational Innovation Vol 12, 205-219. 